Artur GRUSZCZAK

Jagiellonian University in Kraków

artur.gruszczak@uj.edu.pl

\title{
EUROPEAN BORDERS IN TURBULENT TIMES: THE CASE OF THE CENTRAL MEDITERRANEAN 'EXTENDED BORDERLAND'
}

ABSTRACT This article presents one of the most salient aspects of the migration crisis in the EU, namely the turbulent management of external borders, and analyzing it in the case of the central region of the Mediterranean Sea. The study is focused on risks and threats to the security of the European Union and its member states, particularly Italy, posed by negative aspects of migratory flows and accompanying phenomena such as migrant smuggling, trafficking in human beings, drug smuggling or document frauds. For this purpose, a concept of 'extended borderland' is applied as particularly suitable for analyzing border-security policies and actions undertaken by the European Union. The argument developed in this article is that the Central Mediterranean area has been converted into an extended borderland where conventional systems, methods and tools of border management are superseded by spatial taming created by international actors acting through joint maritime operations.

Key words: European Union, migration crisis, borders, extended borderland

The European Union is one of the most attractive areas for international migrants and has long been one of their main destinations. According to Eurostat, in 2016 the number of people living in the EU who were citizens of non-member countries was 20.7 million (4 percent of the total EU population) while the number of people who had been born outside of the EU was 35.1 million (6.9 percent of the total EU population). ${ }^{1}$ A significant part of immigrant population resides illegally in the EU or does not have

Eurostat, "Migration and Migrant Population Statistics", March 2017, at < http://ec.europa.eu/eurostat /statistics-explained/index.php/Migration_and_migrant_population_statistics>, 29 September 2017. 
the necessary authorization. The total number of such 'irregular' migrants is difficult to be estimated. The number of irregular immigrants detected (found to be illegally present and apprehended by national authorities) on the territory of the EU in 2016 was 983,860 , which meant a significant drop from the record high of 2.2 million in $2015 .{ }^{2}$ However, the overall number of unauthorized residents from non-EU countries is estimated to be much higher as a result of the recent migration crisis in Europe.

Unauthorized immigrants reach the territory of EU Member States following several main transit routes. Traditionally, these routes have been found in the southern and eastern parts of the European continent. The migration crisis which started in 2014 has proved this feature: migrants and asylum seekers have preferred channels and entry points located in the Mediterranean region. The migratory pressure at the external borders of the European Union has produced considerable security dilemmas and challenges confronting not only the 'frontline' countries of the south of Europe but also EU institutions, agencies as well as strategies and policies adopted at the transnational level. The issue of an effective, comprehensive, integrated management of border controls has been put high on the EU's migration and asylum agenda. Moreover, it also has been presented as a top security measure strongly needed for tackling effectively negative consequences of migratory inflows.

This article aims at presenting one of the most salient aspects of the migration crisis in the EU, namely the turbulent management of external borders, and analyzing it in the framework of border studies. ${ }^{3}$ Security aspects of border control and protection will be highlighted and illustrated by the case of the central Mediterranean Sea. Despite building on the mainstream border studies scholarship, this research focuses on risks and threats to the security of the European Union and its member states, particularly Italy, posed by negative aspects of migratory flows and accompanying phenomena such as migrant smuggling, trafficking in human beings, drug smuggling or document frauds. For this purpose, a concept of 'extended borderland' is applied, partially drawing from Brunet-Jailly and Dupeyron's 'agent-power' concept, partially from Martínez's borderland 'paradigms'. The extended borderland perspective is particularly suitable for analyzing border-security policies and actions undertaken by the European Union acting through its institutions, agencies and bodies.

The argument developed in this article is that the Central Mediterranean area has been converted into an extended borderland in which conventional systems, methods and tools of border management are superseded by spatial taming created by international actors acting through joint maritime operations. As a result, territorial waters of

\footnotetext{
Eurostat, "Statistics on Enforcement of Immigration Legislation", at <http://ec.europa.eu/eurostat/ statistics-explained/index.php/Statistics_on_enforcement_of_immigration_legislation>, 29 September 2017.

3 D. Wastl-Walter (ed.), The Ashgate Research Companion to Border Studies, Farnham-Burlington, VT 2011; T.M. Wilson, H. Donnan (eds.), A Companion to Border Studies, Malden-Oxford 2012; N.A. Naples, J. Bickham-Mendez (eds.), Border Politics. Social Movements, Collective Identities, and Globalization, New York-London 2015; L. Weber (ed.), Rethinking Border Control for a Globalizing World. A Preferred Future, Abingdon-New York 2015.
} 
Italy and Libya as well as the central Mediterranean high seas were incorporated into the extended borderland characterized by the emergence of high-intensity conflict ecosystem which considerably diminishes prospects for managing and solving the migratory crisis.

The paper proceeds as follows: the first section discusses the theoretical and conceptual framework of extended borderland with reference to mainstream border studies as well as specific security-oriented concepts of border management and forward protection; the next part draws an overall picture of the consequences of intensive migratory flows in the Mediterranean Basin with a special focus on the central part of this area; the final part provides empirical examples of activities undertaken by the EU and national actors in the Central Mediterranean extended borderland.

\section{EXTENDED BORDERLAND: A CONCEPTUALIZATION}

Border studies truly have boomed since the beginning of the $21^{\text {st }}$ century due to the need to reconsider earlier concepts and theories of borders, bordering and boundaries against the new backdrop of global processes of mobility, transfering and communication as well as de- and re-territorialization. In addition, the security perspective and the view of the border as the state's 'protective shield' against major threats and risks of 'external' provenience have strongly affected the further development of border studies in recent years. A research agenda put forward at the beginning of the present century focused on delineation of new concepts and ideas relating to boundaries which were not part of the traditional study of boundaries - in particular, notions of inclusion and exclusion, non-geographic boundaries, the management of boundaries as institutions and the means through which trans-boundary movement may take place. ${ }^{4}$ However, the effects of 're-bordering's after 9/11 and securitization of state borders have shifted the center of gravity in border studies to the issues of policing, surveillance, remote control, criminal prevention and even militarization. ${ }^{6}$ Therefore, the notion of the border has transgressed not only the traditional framework of theory and analysis, but also those concepts which were formulated in the late $20^{\text {th }}$ century at the dawn of globalization and

4 D. Newman, "On Borders and Power: A Theoretical Framework", Journal of Borderlands Studies, vol. 18, no. 1 (2003), p. 16, at <https://doi.org/10.1080/08865655.2003.9695598>. See also idem, "Contemporary Research Agendas in Border Studies: An Overview", in D. Wastl-Walter (ed.), The Ashgate Research Companion..., pp. 33-47; A. Paasi, "A Border Theory: An Unattainable Dream or a Realistic Aim for Border Scholars?", in D. Wastl-Walter (ed.), The Ashgate Research Companion..., pp. 11-31.

$5 \quad$ P. Andreas, "Redrawing the Line: Borders and Security in the Twenty-First Century", International Security, vol. 28, no. 2 (2003), pp. 78-111, at <http://dx.doi.org/10.1162/016228803322761973>.

6 See for instance Ch. Leuprecht, T. Hataley, R. Nossal (eds.), Evolving Transnational Threats and Border Security. A New Research Agenda, Kingston, Ont. 2012; G. Andreopoulos (ed.), Policing Across Borders. Law Enforcement Networks and the Challenges of Crime Control, New York 2013; C. Kinnvall, T. Svensson (eds.), Governing Borders and Security. The Politics of Connectivity and Dispersal, Abingdon-New York 2015; L. Weber (ed.), Rethinking Border Control... 
digital revolution. Border as a term and a concept was gradually repealed or superseded by such designators as transitional spaces, bounded territories/spaces, borderscapes and borderlands.

The above formulated reflection has accompanied the perception of border issues as part of the processes of European integration. Although some claimed that Europe itself should be represented as borderland, ${ }^{7}$ mainstream research focused on the issue of Europe's confines and Europe's surroundings (neighborhood). This was due to the fact that border studies on contemporary Europe appeared as a reflection on territorial boundaries of the spillover of integrative patterns. That was specifically highlighted during the process of Eastern enlargement in which the issue of 'shifting borders eastward' was discussed in ideological, ethical, territorial, economic, cultural and - last but not least - security terms. Some authors even argued that the process [of Eastern enlargement - A.G.] will eventually entirely reshape the territorial, political, institutional, economic, and perhaps even, cultural contours of the European and Eurasian landmass. 8 However, a parallel enlargement track, that of extending the Schengen free-travel area, pointed to other aspects of border security: the need to modernize, enhance and integrate national systems of management of external borders of the EU and the necessity to reconfigure control and surveillance mechanisms within the Schengen zone due to the abolition of checks at internal borders. As a result, several interesting and valuable conceptual proposals were launched, addressing such matters as trans-European transport networks (the concept of networked border transformed into a mobile, non-contiguous zone $e^{9}$ ), population surveillance and remote 'biopolitical' control (the concepts of biometric bordering, portable borders, biopolitical border and zones of indetermination ${ }^{10}$ ) or deterritorialization and debordering of movement of persons (the concept of cosmopolitan borders $\left.{ }^{11}\right)$.

E. Balibar, "Europe as Borderland", Environment and Planning D: Society and Space, vol. 27, no. 2 (2009), pp. 190-215, at <http://dx.doi.org/10.1068/d13008>.

8 J. O'Brennan, The Eastern Enlargement of the European Union, Abingdon-New York 2006, p. 115.

$9 \quad$ W. Walters, “Border/Control”, European Journal of Social Theory, vol. 9, no. 2 (2006), pp. 187-203, at $<$ https://doi.org/10.1177/1368431006063332>.

10 L. Amoore, "Biometric Borders: Governing Mobilities in the War on Terror", Political Geography, vol. 25, no. 3 (2006), pp. 336-351, at <http://dx.doi.org/10.1016/j.polgeo.2006.02.001>; H. van Baar, "Evictability and the Biopolitical Bordering of Europe", Antipode, vol. 49, no. 1 (2016), pp. 212 230, at <http://dx.doi.org/10.1111/anti.12260>; W. Walters, "Secure Borders, Safe Haven, Domopolitics”, Citizenship Studies, vol. 8, no. 3 (2004), pp. 237-260, at <https://doi.org/10.1080/1362102 042000256989>; A. Cooper, Ch. Rumford, “Cosmopolitan Borders: Bordering as Connectivity”, in M. Rovisco, M. Nowicka (eds.), Ashgate Companion to Cosmopolitanism, Farnham 2011, pp. 261-276; D. Bigo, "Du panoptisme au Ban-optisme. Les micros logiques du contrôle dans la mondialisation", in P.-A. Chardel (ed.), Technologies de contrôle dans la mondialisation. Enjeux politiques, éthiques et esthétiques, Paris 2009, pp. 59-80; idem, "Detention of Foreigners, States of Exception, and the Social Practices of Control of the Banopticon”, in P.K. Rajaram, C. Grundy-Warr (eds.), Borderscapes. Hidden Geographies and Politics at Territory's Edge, Minneapolis-London, pp. 3-33.

11 A. Cooper, Ch. Rumford, "Cosmopolitan Borders...”. 
The issue of surroundings ('external environment', 'outer space' or neighborhood) of the European Union has prevailed in border studies since the beginning of the present century. It was underlined that the EU's neighborhood is a source of a wide range of 'non-traditional' security threats and risks such as terrorism, migratory movements, organized crime, poverty and civil wars, which need to be prevented and deterred by an effective cooperation in home affairs and integrated management of external borders. Moreover, an external action is also necessary to address challenges posed by structural causes of instability, poverty and weaknesses of states and societies in third countries, especially those of the 'global South.12 Highlighting the human dimension of security (human security), which encompasses access to basic goods and services, healthy and safe environment, protection from physical violence and preservation of traditional values and identities as well as protection of civil and political rights, the European Union has placed a special emphasis on humanitarian aspects of its neighborhood policy seeking to link together 'exclusionary' effects of its security policies (border protection, prevention and fight against criminality and terrorism, combating illegal migration and human smuggling) with 'inclusionary' mechanisms (financial aid and technical assistance, humanitarian actions, integration of immigrants). In this context, external borders of the EU were perceived from a specific multidimensional perspective, combining 'borderwork' with protective measures at the borders, forward presence in the neighborhood as well as proactive initiatives for neighboring states and societies.

The concept of borderland appears to be especially adequate to take up the matters related to borders, boundaries and confines of the European integration space. However, hitherto concepts and theoretical proposals seem to lack satisfactory explanatory elements, particularly in the face of new security demands concerning border controls and immigration control which have loomed large since the beginning of the recent migration crisis. Therefore, a notion of 'extended borderland' is going to be introduced and explained.

Oscar Martínez built a complex set of models ('paradigms' ${ }^{\text {'13) }}$ of borderlands underlining dynamics and complexity of interactions based on cross-border movements. $\mathrm{He}$ distinguished four types of borderlands: (1) alienated, (2) coexistent, (3) interdependent, and (4) integrated. Alienated borderlands preclude ordinary, regular cross-border traffic and interchange because of fundamental structural obstacles such as animosity, rivalry, disputes, political antagonisms and military tensions. Coexistent borderlands emerge when border-related conflicts are reduced to a scope enabling cross-border cooperation though maintained at a relatively low level, particularly in social and economic dimensions. Interdependent borderlands are founded on the symbiosis between adjacent border regions stimulating growth and development by an intense mutually beneficial exchange of goods, services, capital and labour. Integrated borderlands blur

12 See P. Rieker (ed.), External Governance as Security Community Building. The Limits and Potential of the European Neighbourhood Policy, London 2016; Ch. Kaunert, S. Léonard (eds.), European Security Governance and the European Neighbourhood after the Lisbon Treaty, London-New York 2013.

13 O.J. Martinez, "The Dynamics of Border Interaction. New Approaches to Border Analysis", in C.H. Schofield (ed.), Global Boundaries. World Boundaries, vol. 1, London-New York 1994, p. 2. 
in practice political, territorial, market and cultural division lines typical for the classical concept of sovereignty. Societies and markets merge, border controls are dismantled, an intense diffusion of cultural patterns, technology and knowledge underpins the emergence of an economic, cultural and societal borderland community. ${ }^{14}$

I wish to enrich this taxonomy by adding the fifth model, that of extended borderland. It is based on a sharp asymmetry between bordering regions (or communities, or states) which triggers both asymmetrical forms of cross-border interactions and strange heterarchical loops. ${ }^{15}$ Asymmetry does not necessarily entail imbalance, rather it encompasses the techniques of resilience and restraint ${ }^{16}$ tending to differentiation and connectivity reflected in general-purpose and task-specific matters. Asymmetry also refers to 'strategic mindsets' of actors determining the dynamic of developments and processes unfolding in an extended borderland. As Breen and Geltzer underline, asymmetric strategies transform an adversary's perceived strength into a vulnerability, often by revealing one's own perceived vulnerability as a strength. ${ }^{17}$

Extended borderland blends 'hard' with 'soft' facts, i.e. strict, institutionalized protective and security-oriented measures at the borders with social and cultural phenomena determining construction of boundaries. ${ }^{18}$ This division corresponds with Hassner's distinction between fixed borders and moving borderlands. ${ }^{19}$ In addition, extended borderland addresses the issue of 'porosity' of borders in a selective way, including mechanisms of deterrence and border sealing as well as active forward presence and rapid reaction.

Extended borderland is replete with a host of actors (local/national, borderland/ cross-border, international and transnational) performing the whole variety of roles, functions and tasks within a given borderland. Their competences sometimes overlap, sometimes clash, which results in the emergence of a specific dense networked environment based on symbiotic coexistence. It incorporates agent power of individual ties and forces, broad social processes framing individual actions, and norms and institutions (formal and informal) as well as culture and identity (self-awareness) of a borderland. ${ }^{20}$ Such an 'ecosystem' fosters mechanisms of self-reference and reproduction which underpin the logic of confrontation and cooperation.

14 Ibid., pp. 2-5.

15 See D. Hofstadter, I Am a Strange Loop, New York 2007, pp. 102-110.

16 J. Leech, Asymmetries of Conflict. War without Death, London-New York 2014, p. xv.

17 M. Breen, J.A. Geltzer, "Asymmetric Strategies as Strategies of the Strong”, Parameters, vol. 41, no. 1 (2011), p. 41.

18 See K. Eder, "Europe's Borders. The Narrative Construction of the Boundaries of Europe", European Journal of Social Theory, vol. 9, no. 2 (2006), pp. 255-271, at <https://doi.org/10.1177/ $1368431006063345>$.

19 P. Hassner, "Fixed Borders or Moving Borderlands? A New Type of Border for a New Type of Entity", in J. Zielonka (ed.), Europe Unbound. Enlarging and Reshaping the Boundaries of the European Union, London-New York 2002.

20 See E. Brunet-Jailly, B. Dupeyron, "Introduction. Borders, Borderlands, and Porosity”, in E. Brunet-Jailly (ed.), Borderlands. Comparing Border Security in North America and Europe, Ottawa 2007, p. 1. 
Extended borderland is a kinetic system of interconnected actors, rules and resources existing in vast communication, political, economic and - last but not least territorial realms. The latter means that boundaries of extended borderland are not confined to a delimited territory, even if it is administratively established. Due to the networked architecture of extended borderland, its boundaries move beyond administrative/territorial frontiers. Spontaneous movements and varied forms of exchange emerge as a consequence of synergetic connections between the actors and expected gains from arbitration in situations of conflict or feud.

\section{THE MIGRATION CRISIS IN THE EU AND CENTRAL MEDITERRANEAN}

Immigration to the EU has been influenced by numerous political, economic and social factors originating in neighboring regions and more distant areas. Economic prosperity, public order and political stability have been attracting both economic immigrants and refugees. The EU's neighborhood since the late 1980s has generated migratory pressure resulting from social and political crises (Eastern Europe), protracted instability (the Middle East), civil wars (the Balkans), long-term military campaigns (South Asia), ethnic conflicts (Turkey, the Balkans) or revolutions (North Africa). Immigrants from the Balkans, Eastern Europe or Turkey have been motivated mostly by economic gains, social benefits and career opportunities. Victims of armed conflicts, violence and oppression in the Middle East, South Asia and North Africa have been heading for Europe as the closest refuge. People suffering extreme poverty, hunger, famine or inhuman exploitation in the Horn of Africa and sub-Saharan part of the African continent have chosen Europe as a sanctuary. Immigration also has been triggered by humanitarian principles applicable in the European Union, particularly the right to family reunification and protection of asylum seekers and refugees. ${ }^{21}$

Following the migration crisis in the early 1990s, provoked by the massive inflow of nationals of East European countries in the wake of the fall of Communist regime and acute protracted economic crisis, the European Union sought to set some formal standards and adopt legal instruments facilitating cross-border movements of persons and enhancing effectiveness of the management of external borders and asylum policies. It brought about certain achievements in the field of asylum, visa, migration and border management enough to manage migratory flows effectively and avoid serious crises. ${ }^{22}$

The second decade of the $21^{\text {st }}$ century began with turbulent developments in the EU's neighborhood. The turmoil in North Africa, provoked by anti-government up-

21 See A. Gruszczak, "Immigration Control and Securing the EU's External Borders", in E. Stadtmüller, K. Bachmann (eds.), The EU's Shifting Borders. Theoretical Approaches and Policy Implications in the New Neighbourhood, London-New York 2012, pp. 213-226.

22 G. Lahav, Immigration and Politics in the New Europe. Reinventing Borders, Cambridge 2004; S. Peers, N. Rogers (eds.), EU Immigration and Asylum Law (Text and Commentary), Leiden-Boston 2006. 
risings during the so-called Arab Spring in 2011 and the subsequent NATO's military intervention in Libya to topple longtime dictator Muammar Gaddafi, generated massive emigration to the EU in the region of the Central Mediterranean. The escalation of the civil war in Syria, the emergence and quick expansion of the Islamic State in Iraq and Syria, the protracted internal conflicts in Iraq and Afghanistan and the chronic instability in the Horn of Africa were additional factors contributing to the intensification of migratory flows toward Europe. Insufficient control of external borders of the EU's southern member states, especially Greece, provoked the flood of refugees and asylum seekers. The number of asylum applications lodged in EU member states rose from 257,000 in 2010 to 435,000 in 2013, 562,680 in 2014 and 1,321,600 in 2015. This exceptionally high number of applications was maintained in 2016, amounting to 1,233,340. ${ }^{23}$ According to Eurostat, 61 percent of first time asylum applicants in 2016 originated from Syria, Afghanistan, Pakistan, Iran and Iraq. ${ }^{24}$

As mentioned in the introduction, the rapid increase in the number of asylum seekers in the European Union coincided with a skyrocketing level of irregular immigration. The latter reflected serious security flaws at external borders and a substantive level of criminalization of migrants due to the use of illegal services offered by organized criminal gangs offering 'facilitated access' to the territory of EU member states by land or maritime routes. It was estimated that 90 percent of irregular migrants who reached the EU in 2015 used 'facilitation services'. The number of facilitators detected was over 12,000. Europol claimed that the criminal assets from migrant smuggling could amount to around 3-6 billion Euro..$^{25}$ Likewise, the number of iregular crossings of the EU's external borders increased dramatically in 2015 , reaching $1,822,337$ cases registered by Frontex on the basis of information provided by national border authorities from EU member states. As a reference, it is worth providing relevant data from previous years: 282,962 in $2014,107,365$ in 2013 and barely 72,437 in $2012 .{ }^{26}$

Against the general backdrop of the migration crisis which started to arise in 2013 and loomed large in 2015, the Mediterranean Basin was considered as a 'soft underbelly' of the European continent. Indeed, the main migratory routes were concentrated in that region whereas the eastern borders of the EU member states, against all forecasts on the eve of the eastern enlargement of the European Union, were well guarded and

23 Eurostat, "Asylum Statistics", 13 March 2017, at <http://ec.europa.eu/eurostat/statistics-explained/ index.php/Asylum_statistics>, 14 October 2017; Refugee Council Information, Asylum Seekers in Europe, March 2017, at <https://www.refugeecouncil.org.uk/assets/0004/0083/Asylum_in_Europe _March_2017.pdf>, 14 October 2017.

24 Eurostat, News Release, no. 46 (16 March 2017), at <http://ec.europa.eu/eurostat/documents/ 2995521/7921609/3-16032017-BP-EN.pdf/e5fa98bb-5d9d-4297-9168-d07c67d1c9e1 >, 14 October 2017.

25 Europol, Migrant Smuggling in the EU, February 2016, at <https://www.europol.europa.eu/sites/ default/files/documents/migrant_smuggling_europol_report_2016.pdf>, 18 March 2016.

26 Frontex, Annual Risk Analysis 2014, Warsaw, May 2014, p. 14; Frontex, Annual Risk Analysis 2016, Warsaw, March 2016, p. 16; Frontex, Annual Risk Analysis 2017, Warsaw, February 2017, p. 16. 
only incidentally crossed by irregular migrants. ${ }^{27}$ The Central Mediterranean constituted one of the main footbridges connecting the European continent with outer lands, namely the central section of the North African coast. Despite migratory pressure existing since the 1990s, the Central Mediterranean did not generate massive flows of migrants of asylum seekers. Unlike the western part of the Mediterranean, cumulating migration from Western Africa and Morocco heading for Spain, the central part represented occasional streams of migrants departing from Libya toward the Italian islands of Lampedusa and Sicily as well as toward Malta. As a result of the treaty of Friendship, Partnership and Cooperation between Italy and Libya signed on 30 August 2008, coast guards of both countries began cooperating in intercepting and forcibly returning to Libya 'boat people' on the high seas, which had a clearly deterrent effect.

The Arab Spring in 2011 resulted in the rising wave of refugees from North Africa: initially from Tunisia, then from Libya. The Italian island of Lampedusa became the main target for migrants. Their number, as detected for illegal border crossings, amounted to 64,261 in 2011, compared to 4,450 in the previous year. ${ }^{28}$ Although a significant drop in the number of illegal border crossings occurred in 2012 (barely 10,000 cases), the following year witnessed chaos in Libya, inflow of refugees from the Horn of Africa and the emergence of migrant smuggling networks. Risks associated with the long maritime route leading through high seas and the distance of $300 \mathrm{kms}$ between Libyan shore and Lampedusa as well as the active presence of Libyan and Italian coast guards on their respective territorial waters ceased to be the principal deterrent factor. Masses of migrants found themselves in a desperate position, which makes them committed to risking their lives on a dangerous and exhausting trip to Europe. Tragic wreckages of overcrowded ships and boats as well as the rising death toll in the Central Mediterranean did not discourage African migrants from searching for every opportunity to get to European shores while putting their life at risk. As a consequence, the number of detections of illegal border crossings on the Central Mediterranean route saw a fourfold increase compared to 2012. ${ }^{29}$ This trend remained in 2014, when the number of detections jumped to over 170,000 , which represented $60 \%$ of all illegal border crossings in the EU. Syrian refugees were the main group, ahead of traditional migrant nationalities of Eritreans, Somalis and Nigerians. ${ }^{30}$

On the eve of the migration crisis which erupted in the summer of 2015, the Central Mediterranean turned into extended borderland characterized by high intensity of migratory flows, a growing number and variety of actors and increasingly complex interconnections. Firstly, push factors generated in North Africa resulted to be persistent, long-term and dynamic. Therefore, endemic sources of instability, popular grievances and general discontent determined the kinetics of interactions between domestic, in-

\footnotetext{
For instance, in 2011 illegal crossings of the eastern borders route made up barely 0.7 percent of all registered cases. See Frontex, Annual Risk Analysis 2012, Warsaw, April 2012, p. 14.

28 Frontex, Annual Risk Analysis 2012, p. 46.

29 Frontex, Annual Risk Analysis 2014, p. 30.

30 Frontex, Annual Risk Analysis 2015, Warsaw, April 2015, pp. 18-20.
} 
ternalized and international actors, making them focus on exit strategies of migrants and deterrence strategies of potential host countries in the EU.

Secondly, the territorial disconnection in the Central Mediterranean initially eliminated direct encounters of the main actors of the migratory/refugee ecosystem, namely migrants, asylum seekers, the authorities of the countries playing prominent roles in this region (mainly Italy, Malta, Tunisia and Libya) and international rescue groups, because of the existence of a relatively vast area of 'no-man's waters': the high seas under international law of the sea. However, the growing number of sea incidents involving migrants and refugees, and especially the rising death toll, caused a reconfiguration of that ecosystem toward the reinforcement of search-and-rescue capabilities and elevated activeness of the main adversary actors: coast guards, criminal organizations and international humanitarian groups. As a result, the previously 'neutral' waters between the territorial seas got populated by different categories of actors following often contradictory rules and principles, yet united in the shared objective of turning the high seas in the Central Mediterranean to a kinetic ecosystem of extended borderland. As van Reekum tartly observed, all those involved - guards, smugglers, activists, researchers, migrants, aid workers, data engineers, politicians - have begun to incorporate in their practices the conflation of unauthorized passage and distress at sea. Emergency has become expected, recurrent and planned. ${ }^{31}$

Thirdly, the 'migration crisis' was triggered by the dynamic political events in the Middle East and North Africa which generated massive flows of migrants to Europe, especially in the eastern part of the Mediterranean. However, its structural causes were much more intricate and lied in accelerated economic, ideological, cultural and technological processes shaping identities in the globalized world. ${ }^{32}$ In addition, its dynamics was determined by humanitarian issues which were politicized and mediatized against the wide backdrop of 'European values', respect for and protection of human rights as well as the tradition of the post-colonial inclusionary approach toward immigrants. ${ }^{33}$ Pallister-Wilkins rightly noticed that the Mediterranean 'migration crisis' is the result of a complex socio-political landscape, genealogies of struggle, geopolitical upheavals and everyday political practices. ${ }^{34}$ One should add to this observation, as the fourth argument, a reflection on the emergence and consolidation of the 'virtual' dimension of the central Mediterranean extended borderland as one of the key variables of the migration crisis. The global expansion of communication technologies has increased mobility

31 R. van Reekum, "The Mediterranean: Migration Corridor, Border Spectacle, Ethical Landscape", Mediterranean Politics, vol. 21, no. 2 (2016), p. 339, at <https://doi.org/10.1080/13629395.2016.1145 $828>$.

32 See T.M. Wilson, H. Donnan, "Borders and Border Studies", in iidem (eds.), A Companion to Border Studies, pp. 7-12, at <http://dx.doi.org/10.1002/9781118255223.ch1>.

33 See interesting remarks by Dario Melossi in: "The Processes of Criminalization of Migrants and the Borders of 'Fortress Europe'”, in J. McCulloch, S. Pickering (eds.), Borders and Crime. Pre-Crime, Mobility and Serious Harm in an Age of Globalization, Basingstoke-New York 2012, pp. 29-31.

34 P. Pallister-Wilkins, "Interrogating the Mediterranean 'Migration Crisis", Mediterranean Politics, vol. 21, no. 2 (2016), p. 312, at <https://doi.org/10.1080/13629395.2016.1145826>. 
and cross-border movements (of information, material goods, people and capital) and facilitated social networking based on human-to-human transmission of information, ideas and visions. It largely facilitated the planning and following of migratory routes, increasing the chances of reaching Europe's external borders. Likewise, it stimulated the booming of a crime-as-a-service business mode ${ }^{35}$ implemented by migrant smuggling networks in their illicit activities. ${ }^{36}$ Moreover, it legitimized enormous search-and-rescue efforts undertaken by international governmental and non-governmental actors which increased their capacities of detecting, identifying and positioning migrants at sea. Therefore, 'virtualization' of the SAR ecosystem reinforced the complex nature of the central Mediterranean extended borderland.

Reorientation of migrant flows in the summer of 2015 in the wake of the opening of the eastern Mediterranean route through the Aegean Sea reduced pressures in the central part of the Mediterranean. The overall number of illegal border crossings in the EU fell threefold in 2016 (to 511,371) due to the EU-Turkey declaration which provided for substantive EU's financial assistance to Turkey and Turkey's agreement to secure its maritime and land borders facing increased migratory pressures. This political act brought about a drastic reduction of migrants crossing Turkish-Greek maritime border in the Aegean Sea or seeking alternative routes. Meanwhile, the quickly growing number of migrants from Africa (reaching the record high of over 170,000 in 2016) shifted the point of gravity from the eastern part of the Mediterranean back to its central area. The number of detections of illegal border crossings in the Central Mediterranean rose by $18 \%$ in 2016 and amounted to 181,459, almost reaching the level of the eastern Mediterranean $(182,277) \cdot{ }^{37}$ As mentioned above, the huge majority were nationals of African countries, arriving from sub-Sahara, West Africa and the Horn of Africa. Traditional nationalities such as Somalis and Eritreans were outnumbered by Nigerians. This trend was reinforced in the first half of 2017. The number of illegal border crossings in the Central Mediterranean kept its growth rate, substantially exceeding appropriate indicators in the eastern part of the Mediterranean. ${ }^{38}$

This has represented a considerable challenge for state and intergovernmental actors involved in managing the complex central Mediterranean borderland. Pull factors generated by SAR operations and increasingly competitive smuggling groups (which considerably reduced the price for a boat journey from Libya's shore to the SAR area ${ }^{39}$ )

35 Europol, Migrant Smuggling..., p. 9.

36 According to Frontex, 96\% of newly-arrived migrants interviewed in the Central Mediterranean region stated that they had used the services of smuggling networks to illegally enter the EU - Frontex, Annual Risk Analysis 2017, p. 8.

37 Ibid., p. 19.

38 The number of illegal border crossings in the central Mediterranean was 24,296 in the first quarter of 2017, whereas in the eastern Mediterranean amounted to roughly 6,000. See Frontex, FRAN Quarterly, no. 1 (2017), p. 8, at <http://frontex.europa.eu/assets/Publications/Risk_Analysis/FRAN_ Q1_2017.pdf>, 14 October 2017.

39 See M. Micallef, The Human Conveyor Belt. Trends in Human Trafficking and Smuggling in Post-revolution Libya, Global Initiative against Transnational Organized Crime, Geneva, March 2017, p. 45. 
'awakened' migrants from those parts of Africa which suffered poor economic and social conditions as well as political instability and ethnic conflicts instead of civil war, indiscriminate violence or extreme poverty, which dominated as push factors in the case of Syria, Afghanistan, Eritrea or Somalia. The extension of the central Mediterranean borderland helped to tackle the humanitarian crisis but produced negative effects for border management and surveillance policies performed by European states either individually (Italy) or in joint international operations.

The following subchapter seeks to analyze the most relevant forms of international activities undertaken in the Central Mediterranean by the key collective actors of European security.

\section{INTERNATIONAL OPERATIONS IN THE CENTRAL MEDITERRANEAN}

The Mediterranean region since the early 2000s has been an area of active international engagement in security-related missions and operations. If taken in broad terms, this area has witnessed numerous UN-led peace-keeping operations concentrating international efforts in the Middle East. The Arab-Israeli conflict, the civil war in Lebanon and the Palestine question forced the United Nations to keep 'blue helmets' in that explosive region. Moreover, the internal strife and division of Cyprus as well as the wars in the former Yugoslavia added new hotspots to the Mediterranean imbroglio. UN missions were deployed also there, seeking to prevent further escalation of violence. ${ }^{40}$

However, all those UN-led operations were land-based; they were not entailing a massive navy presence and were conducted rather far from maritime operational theatre. Other multinational security actors in the Euro-Atlantic area possessed their maritime assets in the Mediterranean. In 1992, NATO activated its Standing Naval Force of Mediterranean (STANAVFORMED), with headquarters in Naples. Its objectives included operational training, visits to various ports of the Mediterranean basin and the Black Sea as well as maritime inspections contributing to the enforcement of weapons embargo against Yugoslavia. ${ }^{41}$ The Western European Union was also strengthening its presence in the Mediterranean basin. Since 1992, it supported NATO's STANAVFORMED in ensuring effective embargo in the Adriatic. ${ }^{42}$ In 1996, it put forward an initiative of a multinational on-call naval force EUROMARFOR, capable to launch within days and carry out joint crisis management operations. ${ }^{43}$

40 See G. Kostakos, "UN Peace-keeping Missions in the Mediterranean Region”, in R. Gillespie (ed.), Mediterranean Politics, vol. 1, London-Cranbury, NJ 1994, pp. 58-71.

41 J.G. Gade, P.S. Hilde, "NATO and the Maritime Domain", in J.I. Bekkevold, G. Till (eds.), International Order at Sea. How it Is Challenged. How it Is Maintained, London 2016, p. 118.

42 B. Germond, The Maritime Dimension of European Security. Seapower and the European Union, Basingstoke-New York 2015, pp. 155-156.

43 Idem, "Multinational Military Cooperation and its Challenges: The Case of European Naval Opera- 
Only the beginning of the $21^{\text {st }}$ century brought an important change, extending the reach of international operations onto maritime area. In the wake of the 9/11, NATO launched its maritime operation "Active Endeavour" patrolling the Mediterranean and monitoring ships in order to help deter and prevent terrorist-related activities. In March 2003, the operation was expanded to include escorts through the Straits of Gibraltar provided to non-military ships from NATO member states upon their request. Since mid-2004, "Active Endeavour" covered the whole of the Mediterranean. Whenever required, the operation was supported by STANAVFORMED, which in 2005 was renamed Standing NATO Maritime Group 2 (SNMG2). At that time, NATO partners started contributing with logistical and information support and even, since 2006, deploying vessels. In 2010, following the adoption of a new operational plan, "Active Endavour" shifted from platform-based to a network-based operation, using a combination of on-call units and surge operations instead of deployed forces. ${ }^{44} \mathrm{New}$ tasks were added, particularly information gathering and analysis for the sake of improved Maritime Situational Awareness.

With the increasing intensity of migration flow across the Mediterranean, both nation states and international actors began to reformulate their policies and reconsider the scope and nature of their military presence in that region. A significant difference could be noticed between the EU's and NATO's approach to the migration issue as well as its direct and anticipated consequences. The European Union highlighted humanitarian aspects of migratory flows, pointing to root causes of the increasing scale of migration and displacements such as political instability in North Africa in the wake of the Arab Spring, the civil war in Syria, protracted conflicts in Iraq and Afghanistan, poverty and state failure in the Horn of Africa. The growing number of human tragedies, including drowning deaths in the Mediterranean, mobilised the Union to undertake search and rescue actions to prevent further loss of life at sea. In addition, EU officials were aware of the fact that the massive flow of people from Africa and the Middle East was partially stimulated and accelerated by numerous criminal gangs involved in organized trafficking in human beings and smuggling of people. Therefore, they were committed to start fighting the smugglers by systematic monitoring, surveillance and patrolling Mediterranean waters to detect, identify, capture and destroy suspected boats and vessels before they are used by traffickers. NATO was more preoccupied with security consequences and potential risks and threats to the Alliance's stability and safety posed by massive migratory flows toward Europe.

Well before the European Union took formal steps and adopted necessary legal measures, one of its member states, namely Italy, ${ }^{45}$ had launched a maritime operation

tions in the Wider Mediterranean Area", International Relations, vol. 22, no. 2 (2008), pp. 181-183, at $<$ https://doi.org/10.1177/0047117808089894>.

44 "Operation Active Endeavour", NATO, at <https://www.nato.int/cps/ic/natohq/topics_7932. htm>, 12 October 2017.

45 Italy participated in a maritime international operation already in 1997. Facing political chaos as well as social and economic decay in Albania, Italy took a lead in multinational military force established on grounds of UN Security Council's resolution 1101. Although the coalition of 11 European states 
dubbed "Mare Nostrum" in order to tackle the dramatic increase in immigration flows from North Africa and intensify proactive search and rescue (SAR) activities in the Strait of Sicily. The operation began in October 2013 and was triggered by a tragedy close to the shores of Lampedusa where an overcrowded fishing boat with more than 500 Eritreans and Somalis smuggled by an armed gang sank off the coast. $366 \mathrm{mi}-$ grants died. ${ }^{46}$ The operation engaged at least 1,000 personnel from Italian armed forces (mainly Navy and Air Force) supported by the Coast Guard, Police, Carabinieri and Financial Police as well as Red Cross military corps and governmental agencies involved in migratory policy. ${ }^{47}$ It lasted one year before it was superseded in October 2014 by the EU-led operation "Triton". "Mare Nostrum" was a relative success in humanitarian terms. More than 140,000 people were rescued.$^{48}$ However, it constituted a serious organizational and military effort as well as a financial burden for the Italian government. Its costs equaled EUR 9 million per month and the EU contributed with roughly EUR 1.8 million. Moreover, some observers criticized its counterproductive effect in terms of tackling the migration challenge. They argued that effective SAR activities are an undesirable pull factor, encouraging more migrants to attempt sea crossing and thereby leading to more tragic and unnecessary deaths. ${ }^{49}$

The operation "Triton" was coordinated by Frontex (then EU Agency for the Management of Operational Cooperation at the External Borders of Member States) as one

was tasked to restore order and prevent Albania from further descending into anarchy and lawlessness, it also sought to stop massive migration outflows from Albania, including interception and return of Albanian migrants. See R. Marchiò, "Operation Alba". A European Approach to Peace Support Operations in the Balkans, Carlisle, PA 2000; B. Germond, E. Grove, Maritime Security in the Mediterranean. European and Transatlantic Approaches, Mediterranean Paper Series, The German Marshall Fund of the United States, Washington 2010, p. 14. In 2004, an operation "Constant Vigilance" started in the Central Mediterranean aiming at surveillance, search and rescue of migrants leaving North African territorial waters. Following the Arab Spring, the Italian Navy conducted 139 rescue missions in the years 2011-2013, saving more than 16,000 people. See P. Cuttitta, "Humanitarianism and Migration in the Mediterranean Borderscape: The Italian-North African Border between Sea Patrols and Integration Measures", in C. Brambilla et al. (eds.), Borderscaping. Imaginations and Practices of Border Making, London-New York 2016, p. 131; E. Cusumano, "Emptying the Sea with a Spoon? Non-governmental Providers of Migrants Search and Rescue in the Mediterranean”, Marine Policy, vol. 75 (2017), p. 92, at <http://dx.doi.org/10.1016/j.marpol.2016.10.008>.

46 L. Davies, "Lampedusa Boat Tragedy is 'Slaughter of Innocents' Says Italian President”, The Guardian, 3 October 2013, at <https://www.theguardian.com/world/2013/oct/03/lampedusa-boat-tragedyitaly-migrants $>, 12$ October 2017.

47 “Mare Nostrum Operation”, Ministero della Difesa, at <http://www.marina.difesa.it/EN/operations /Pagine/MareNostrum.aspx>, 10 October 2017.

48 "Operation Mare Nostrum to End - Frontex Triton Operation Will Not Ensure Rescue at Sea of Migrants in International Waters", Asylum Information Database, 13 October 2014, at <http://www. asylumineurope.org/news/13-10-2014/operation-mare-nostrum-end-frontex-triton-operation-willnot-ensure-rescue-sea>, 12 October 2017.

49 A. Taylor, "Why Britain Won't Save Drowning Migrants in the Mediterranean", The Washington Post, 28 October 2014, at <https://www.washingtonpost.com/news/worldviews/wp/2014/10/28/ why-britain-wont-save-drowning-migrants-in-the-mediterranean/?utm_term $=. d 5 f 885729210>$, 12 October 2017. 
of its joint operations. ${ }^{50}$ Launched in November 2014, it had similar humanitarian tasks as "Mare Nostrum" yet much more limited political objectives, territorial reach and financial resources. It was planned as a border mission aiming to ensure effective surveillance and border control in the Mediterranean region and especially support Italian authorities in protecting Italy's maritime borders from massive irregular crossing by migrants. It was focused on Italy's territorial waters (within a radius of 30 nautical miles from the Italian coast) and not international waters, where the largest number of migrants were exposed to the risk of drowning or death by dehydration. Moreover, its initial budget was roughly EUR 2.9 million per month and EU member states' equipment contribution was limited to two surveillance aircrafts and three patrol vessels. ${ }^{51}$

Similarly to the sinking of the boat with Somali and Eritrean migrants in October 2013, another terrible tragedy occurred in the Central Mediterranean. On 19 April 2015, a Libyan trawler with over 850 migrants aboard sank in the high seas between Libya's coast and the Italian island of Lampedusa. Despite a coordinated massive rescue operation, only 28 migrants survived. ${ }^{52}$ Following the EU summit several days after the tragedy, the operation "Triton" shifted from surveillance and border protection to SAR operation in a far more extended zone: 138 nautical miles south of Sicily. Moreover, the technical assets were strengthened and the budget was tripled. ${ }^{53}$ Nevertheless, poor equipment and a small multinational staff involved in this operation did not help reducing either the number of migrants crossing the central Mediterranean maritime area or the death toll and the scope of human smuggling.

Following the April 2015 migrant boat tragedy, the European Union decided to run another mission: that time under the Common Security and Defence Policy, with the aim of preventing further loss of life at sea and to tackle the root causes of the human emergency. ${ }^{54}$ On 18 May 2015, the Council adopted a decision on the European Union military operation in the Southern Central Mediterranean (EUNAVFORMED) $)^{55}$ which was launched in late June 2015. Three months later, the mission was renamed Operation "Sophia". It was designed as a military crisis management operation contributing to

50 R. Mungianu, Frontex and Non-Refoulement. The International Responsibility of the EU, Cambridge 2016, pp. 200-202.

51 European Commission, “Frontex Joint Operation 'Triton' - Concerted efforts to manage migration in the Central Mediterranean”, MEMO/14/566, Brussels, 7 October 2014, at <http://europa.eu/ rapid/press-release_MEMO-14-566_en.htm>, 10 October 2014.

52 P. Kingsley, A. Bonomolo, S. Kirchgaessner, "700 Migrants Feared Dead in Mediterranean Shipwreck", The Guardian, 19 April 2015, at <https://www.theguardian.com/world/2015/apr/19/700migrants-feared-dead-mediterranean-shipwreck-worst-yet>, 12 October 2017.

53 Frontex, "Frontex expands its Joint Operation Triton", 26 May 2015, at <http://frontex.europa.eu/ news/frontex-expands-its-joint-operation-triton-udpbHP>, 12 October 2017.

54 European Council, "Special meeting of the European Council, 23 April 2015 - statement", at <http:// www.consilium.europa.eu/en/press/press-releases/2015/04/23/special-euco-statement/>, 24 April 2015.

55 Council Decision (CFSP) 2015/778 of 18 May 2015 on a European Union military operation in the Southern Central Mediterranean (EUNAVFOR MED), Official Journal of the European Union, L 122, 19 May 2015. 
the disruption of the business model of human smuggling and trafficking networks in the Southern Central Mediterranean. ${ }^{56}$ It was planned to unfold in three sequential phases: (1) information gathering and patrolling on the high seas to support the detection and monitoring of migration networks; (2) conduct boarding, search, seizure and diversion of vessels suspected of being used for human smuggling or trafficking, initially acting on the high seas, next operating in both territorial and internal waters of the 'coastal state', namely Libya; (3) all necessary measures against vessels used for human smuggling or trafficking, also through disposing of them or rendering them inoperable. ${ }^{57} \mathrm{De}-$ spite tackling human smuggling and criminal networks, EUNAVFOR MED quickly transformed into classical SAR forces with some extended specific tasks including the training of the Libyan Coast Guard and Navy, conducting surveillance and gathering information on illegal trafficking of oil exports from Libya as well as enhancing the possibility for sharing information on human trafficking with member states' law enforcement services, as well as with EU agencies: Frontex and Europol. However, without permission to enter Libya's territorial waters, ships belonging to Task Force Sophia cannot proceed with Phase $2 \mathrm{~B}$, which is focused on dismantling criminal networks and destroying their assets.

The booming business of illegal migration in the Mediterranean as well as evidences of proliferation of illicit activities (such as drug trafficking, arms smuggling and document frauds) and transmission of threats (terrorism, jihadism and islamic radicalism) into the North Atlantic area activated mechanisms of collective non-article 5 security action. At the Warsaw Summit in July 2016, NATO leaders agreed to launch a maritime operation in the Mediterranean extending the scope of the anti-terror Operation "Active Endeavour". The latter was terminated in November 2016 when "Sea Guardian" became operational. The main purpose of the Operation "Sea Guardian" has been to build and uphold situational awareness, deter and counter terrorism and contribute to maritime capacity building. ${ }^{58}$ "Sea Guardian" was conceptualized as a flexible maritime operation that is able to perform the full range of maritime security tasks, if so decided by the North Atlantic Council. As was the case of "Active Endeavour", NATO's tasks were carried out by the Standing Maritime Group Two (SNMG2) - a multinational, integrated maritime force. Although it was initially deployed on the eastern Mediterranean, SNMG2 began focused security operations in high seas of the Central Mediterranean in early 2017, patrolling the main shipping routes in coordination with aircrafts and submarines provided by the Allies, monitoring maritime traffic and gathering information about vessels.

At NATO's Warsaw summit, the Joint NATO-EU declaration was adopted in order to give new impetus and new substance to the NATO-EU strategic partnership..$^{59}$ The

\footnotetext{
56 Ibid.

57 Ibid.

58 “Operation Sea Guardian”, NATO, at <https://www.nato.int/cps/ua/natohq/topics_136233.htm>, 14 October 2017.

59 "Joint declaration by the President of the European Council, the President of the European Commis-
} 
tasks outlined for both organizations included, amongst others, Broaden [ing] and adapt[ation of] our operational cooperation including at sea, and on migration, through increased sharing of maritime situational awareness as well as better coordination and mutual reinforcement of our activities in the Mediterranean and elsewhere. ${ }^{60}$ The reorganization of NATO's operational activities in the Mediterranean Sea was one of the direct consequences of the Warsaw declaration. In addition, in December 2016 Defence Ministers of the Allies agreed on a common set of proposals for the implementation of the Joint Declaration, including operational cooperation on maritime issues. The ministers announced their will to enhance cooperation and coordination between Operation Sea Guardian and EU NAVFOR MED Sophia in the Mediterranean, through information sharing and logistical support and through practical interaction between the two operations. ${ }^{61}$ As a result, NATO ships carried out focused security patrols in the central Mediterranean Sea, specifically in the international waters off the coast of Libya. SNMG2 operated quite often in the maritime area covered by the EU's "Sophia", which opened up the way for cooperation on information sharing and logistical support, specifically to avoid duplication in tasks and improve the operational picture of maritime activities in the international waters of the central Mediterranean Sea. As to the latter, an independent Maritime Situational Awareness patrol was deployed in mid-2017 in order to reinforce reconnaissance capacities and practice information sharing on a realtime basis.

The above outlined nature and scope of international activities in extended borderland in the Central Mediterranean indicated Pierre Hassner's concept of moving borderlands and fixed borders. The actions undertaken firstly by Italy and then the EU and NATO have shown that the dynamics of migratory issue, especially the massive inflow of migrants to Libya seeking easy transportation routes toward Europe, produced a dual response on the part of European actors. Firstly, the extension of Italian borderland on international waters for humanitarian purposes (SAR actions); secondly, efforts at fixing maritime borders of Italy and Malta exposed to massive illegal crossings. Both Italian and international activities in the central Mediterranean Sea brought about a generally unexpected and unwanted effect of concentrating SAR actions close to the Libyan borderland with a view to reduce the number of fatal incidents and increase the probability of success in the rescue operations. Therefore, the Italian maritime border was in a sense stretched over the vast area between Libya and Italy and its effective protection became subject to coordinated actions carried out by ships participating in NATO's and EU's operations.

sion, and the Secretary General of the North Atlantic Treaty Organization”, NATO, 8 July 2016, at <https://www.nato.int/cps/en/natohq/official_texts_133163.htm>, 10 July 2016.

60

61 Ibid.

"Statement on the implementation of the Joint Declaration signed by the President of the European Council, the President of the European Commission, and the Secretary General of the North Atlantic Treaty Organization", NATO, 6 December 2016, at <https://www.nato.int/cps/ua/natohq/official_ texts_138829.htm>, 8 December 2016. 


\section{CONCLUSIONS}

Turbulences at Europe's borders, which were caused by the massive inflow of migrants and asylum seekers and the sudden local boom for individual and organized human smuggling, have had serious, negative and far-reaching consequences for internal security, international cooperation and public order in the majority of the EU's member states. In this paper, I have presented arguments upholding my claim that the migratory crisis triggered persistent effects of creating a specific migratory ecosystem in the Mediterranean which became deeply rooted in extended borderlands that emerged in the eastern and central regions of the Mediterranean Sea.

The concept of extended borderland highlights the importance of multiple actors present there, their interests and roles as well as interconnected activities undertaken with regard to overall strategy, general objectives or specific goals and selected targets. Symbiotic relationships and synergetic connections have emerged both in horizontal as well as vertical dimensions. From the first perspective, state actors have enhanced cooperation and assistance in order to increase institutional efficiency and political legitimation of their protective and lifesaving measures; non-governmental organizations (NGOs) have activated their human, material and information assets for the sake of effective rescue activities; criminal networks have intensified their illicit business of human smuggling and trafficking taking advantage of weaknesses of state actors (chaos in Libya, limited competences of NATO's and EU's forces; international legal constraints) as well as growing demand on the part of migrant population. Likewise, in such complex migratory ecosystem, specific interactions have become structured between state actors, NGOs and criminal networks. The elimination by the EU and NATO of larger ships and boats utilized by smugglers reduced the chances for a safe transit to the Italian or Maltan borders, yet at the same time moved the center of gravity to the high seas close to Libya's territorial waters. Migrants were boarded on inflatable boats capable to transport them for a relatively short distance off the Libyan coast. The elevated risk of drowning of 'boat people' activated both NGOs and international naval forces deployed in the central Mediterranean Sea to extend their presence near the Libyan territory, which in turn restored migrants' confidence in transportation services offered by smugglers. In some extreme cases, several NGOs were accused of entering into contact with smugglers who preferred to hand over migrants to rescue ships instead of leaving them in the high seas. ${ }^{62}$

Intricate connections between actors and roles they play in extended borderland reflect the phenomenon of conflict ecosystems which are formed in a complex environment encompassing mechanisms of cooperation and discord. They contain both pre-

62 L. Dearden, "Italy Seizes Refugee Rescue Ship Accused of Having Contact with Libyan Smugglers", The Independent, 3 August 2017, at <http://www.independent.co.uk/news/world/europe/italy-refugeerescue-ship-jugend-rettet-libyan-smugglers-mediterranean-migrant-boats-lampedusa-a 7875371 . html>, 16 October 2017; N. Farrell, "Are We Helping Desperate Migrants - or Just People Smugglers?", The Observer, 1 April 2017, at <https://www.spectator.co.uk/2017/04/are-we-helpingdesperate-migrants-or-just-people-smugglers/>, 16 October 2017. 
emptive intervention practices such as those employed by the Italian Navy in the Operation "Mare Nostrum" ${ }^{63}$, as well as repressive measures adopted for law enforcement and restoration and maintenance of order as in the case of the Operation "Sophia" and the Operation "Sea Guardian". While they bring about relative stabilization and de-escalation of tensions and feuds, prospects for termination of conflicts and litigations are postponed indefinitely. The migration crisis in the central region of the Mediterranean Sea has provided numerous evidences for this argument.

\section{BIBLIOGRAPHY}

Amoore L., "Biometric Borders: Governing Mobilities in the War on Terror", Political Geography, vol. 25, no. 3 (2006), at <http://dx.doi.org/10.1016/j.polgeo.2006.02.001>.

Andreas P., "Redrawing the Line: Borders and Security in the Twenty-First Century", International Security, vol. 28, no. 2 (2003), at <http://dx.doi.org/10.1162/016228803322761973>.

Andreopoulos G. (ed.), Policing Across Borders. Law Enforcement Networks and the Challenges of Crime Control, New York 2013.

Baar H. van, "Evictability and the Biopolitical Bordering of Europe", Antipode, vol. 49, no. 1 (2016), at <http://dx.doi.org/10.1111/anti.12260>.

Balibar E., "Europe as Borderland", Environment and Planning D: Society and Space, vol. 27, no. 2 (2009), at <http://dx.doi.org/10.1068/d13008>.

Bigo D., "Detention of Foreigners, States of Exception, and the Social Practices of Control of the Banopticon", in P.K. Rajaram, C. Grundy-Warr (eds.), Borderscapes. Hidden Geographies and Politics at Territory's Edge, Minneapolis-London 2007.

Bigo D., "Du panoptisme au Ban-optisme. Les micros logiques du contrôle dans la mondialisation", in P.-A. Chardel (ed.), Technologies de contrôle dans la mondialisation. Enjeux politiques, éthiques et esthétiques, Paris 2009.

Breen M., Geltzer J.A., "Asymmetric Strategies as Strategies of the Strong", Parameters, vol. 41, no. 1 (2011).

Brunet-Jailly E., Dupeyron B., "Introduction. Borders, Borderlands, and Porosity", in E. Brunet-Jailly (ed.), Borderlands. Comparing Border Security in North America and Europe, Ottawa 2007.

Cooper A., Rumford Ch., "Cosmopolitan Borders: Bordering as Connectivity", in M. Rovisco, M. Nowicka (eds.), Ashgate Companion to Cosmopolitanism, Farnham 2011.

Council Decision (CFSP) 2015/778 of 18 May 2015 on a European Union military operation in the Southern Central Mediterranean (EUNAVFOR MED), Official Journal of the European Union, L 122, 19 May 2015.

63 J. Jeandesboz, P. Pallister-Wilkins, "Crisis, Routine, Consolidation: The Politics of the Mediterranean Migration Crisis", Mediterranean Politics, vol. 21, no. 2 (2016), p. 318, at < https://doi.org/10.1080/1 3629395.2016.1145825>. 
Cusumano E., "Emptying the Sea with a Spoon? Non-governmental Providers of Migrants Search and Rescue in the Mediterranean", Marine Policy, vol. 75 (2017), at <http://dx.doi. org/10.1016/j.marpol.2016.10.008>.

Cuttitta P., "Humanitarianism and Migration in the Mediterranean Borderscape: The Italian-North African Border between Sea Patrols and Integration Measures", in Ch. Brambilla et al. (eds.), Borderscaping. Imaginations and Practices of Border Making, London-New York 2016. Davies L., "Lampedusa Boat Tragedy is 'Slaughter of Innocents' Says Italian President", The Guardian, 3 October 2013, at <https://www.theguardian.com/world/2013/oct/03/lampedusaboat-tragedy-italy-migrants $>$.

Dearden L., "Italy Seizes Refugee Rescue Ship Accused of Having Contact with Libyan Smugglers", The Independent, 3 August 2017, at <http://www.independent.co.uk/news/world/ europe/italy-refugee-rescue-ship-jugend-rettet-libyan-smugglers-mediterranean-migrantboats-lampedusa-a7875371.html>.

Eder K., "Europe's Borders. The Narrative Construction of the Boundaries of Europe”, European Journal of Social Theory, vol. 9, no. 2 (2006), at <https://doi.org/10.1177/ $1368431006063345>$.

European Commission, “Frontex Joint Operation 'Triton' - Concerted efforts to manage migration in the Central Mediterranean”, MEMO/14/566, Brussels, 7 October 2014, at <http:// europa.eu/rapid/press-release_MEMO-14-566_en.htm>.

European Council, "Special meeting of the European Council, 23 April 2015 - statement", at <http:// www.consilium.europa.eu/en/press/press-releases/2015/04/23/special-euco-statement/>.

Europol, Migrant Smuggling in the EU, February 2016, at <https://www.europol.europa.eu/ sites/default/files/documents/migrant_smuggling_europol_report_2016.pdf $>$.

Eurostat, "Asylum Statistics", 13 March 2017, at <http://ec.europa.eu/eurostat/statisticsexplained/index.php/Asylum_statistics $>$.

Eurostat, "Migration and Migrant Population Statistics", March 2017, at <http://ec.europa.eu/ eurostat/statistics-explained/index.php/Migration_and_migrant_population_statistics $>$.

Eurostat, News Release, no. 46 (16 March 2017), at <http://ec.europa.eu/eurostat/ documents/2995521/7921609/3-16032017-BP-EN.pdf/e5fa98bb-5d9d-4297-9168$\mathrm{d} 07 \mathrm{c} 67 \mathrm{~d} 1 \mathrm{c} 9 \mathrm{e} 1>$.

Eurostat, "Statistics on Enforcement of Immigration Legislation", at <http://ec.europa.eu/ eurostat/statistics-explained/index.php/Statistics_on_enforcement_of_immigration_ legislation $>$.

Farrell N., “Are We Helping Desperate Migrants - or Just People Smugglers?”, The Observer, 1 April 2017, at <https://www.spectator.co.uk/2017/04/are-we-helping-desperatemigrants-or-just-people-smugglers/ $>$.

Frontex, Annual Risk Analysis 2012, Warsaw, April 2012.

Frontex, Annual Risk Analysis 2014, Warsaw, May 2014.

Frontex, Annual Risk Analysis 2015, Warsaw, April 2015.

Frontex, Annual Risk Analysis 2016, Warsaw, March 2016.

Frontex, Annual Risk Analysis 2017, Warsaw, February 2017.

Frontex, FRAN Quarterly, no. 1 (2017), at <http://frontex.europa.eu/assets/Publications/Risk_ Analysis/FRAN_Q1_2017.pdf>. 
Frontex, "Frontex Expands its Joint Operation Triton", 26 May 2015, at <http://frontex. europa.eu/news/frontex-expands-its-joint-operation-triton-udpbHP>.

Gade J.G., Hilde P.S., "NATO and the Maritime Domain”, in J.I. Bekkevold, G. Till (eds.), International Order at Sea. How it Is Challenged. How it Is Maintained, London 2016.

Germond B., The Maritime Dimension of European Security. Seapower and the European Union, Basingstoke-New York 2015.

Germond B., "Multinational Military Cooperation and its Challenges: The Case of European Naval Operations in the Wider Mediterranean Area", International Relations, vol. 22, no. 2 (2008), at <https://doi.org/10.1177/0047117808089894>.

Germond B., Grove E., Maritime Security in the Mediterranean. European and Transatlantic Approaches, Mediterranean Paper Series, The German Marshall Fund of the United States, Washington 2010.

Gruszczak A., "Immigration Control and Securing the EU's External Borders", in E. Stadtmüller, K. Bachmann (eds.), The EU's Shifting Borders. Theoretical Approaches and Policy Implications in the New Neighbourhood, London-New York 2012.

Hassner P., "Fixed Borders or Moving Borderlands? A New Type of Border for a New Type of Entity", in J. Zielonka (ed.), Europe Unbound. Enlarging and Reshaping the Boundaries of the European Union, London-New York 2002.

Hofstadter D., I Am a Strange Loop, New York 2007.

Jeandesboz J., Pallister-Wilkins P., "Crisis, Routine, Consolidation: The Politics of the Mediterranean Migration Crisis”, Mediterranean Politics, vol. 21, no. 2 (2016), at <https://doi.org/ 10.1080/13629395.2016.1145825>.

"Joint declaration by the President of the European Council, the President of the European Commission, and the Secretary General of the North Atlantic Treaty Organization”, NATO, 8 July 2016, at <https://www.nato.int/cps/en/natohq/official_texts_133163.htm>.

Kaunert Ch., Léonard S. (eds.), European Security Governance and the European Neighbourhood after the Lisbon Treaty, London-New York 2013.

Kingsley P., Bonomolo A., Kirchgaessner S., "700 Migrants Feared Dead in Mediterranean Shipwreck", The Guardian, 19 April 2015, at <https://www.theguardian.com/world/2015/ apr/19/700-migrants-feared-dead-mediterranean-shipwreck-worst-yet $>$.

Kinnvall C., Svensson T. (eds.), Governing Borders and Security. The Politics of Connectivity and Dispersal, Abingdon-New York 2015.

Kostakos G., "UN Peace-keeping Missions in the Mediterranean Region”, in R. Gillespie (ed.), Mediterranean Politics, vol. 1, London-Cranbury, NJ 1994.

Lahav G., Immigration and Politics in the New Europe. Reinventing Borders, Cambridge 2004. Leech J., Asymmetries of Conflict. War without Death, London-New York 2014.

Leuprecht Ch., Hataley T., Nossal R. (eds.), Evolving Transnational Threats and Border Security. A New Research Agenda, Kingston, Ont. 2012.

Marchiò R., "Operation Alba". A European Approach to Peace Support Operations in the Balkans, Carlisle, PA 2000.

“Mare Nostrum Operation”, Ministero della Difesa, at <http://www.marina.difesa.it/EN/ operations/Pagine/MareNostrum.aspx $>$. 
Martinez O.J., "The Dynamics of Border Interaction. New Approaches to Border Analysis”, in C.H. Schofield (ed.), Global Boundaries. World Boundaries, vol. 1, London-New York 1994. Melossi D., "The Processes of Criminalization of Migrants and the Borders of 'Fortress Europe”, in J. McCulloch, S. Pickering (eds.), Borders and Crime. Pre-Crime, Mobility and Serious Harm in an Age of Globalization, Basingstoke-New York 2012.

Micallef M., The Human Conveyor Belt. Trends in Human Trafficking and Smuggling in Post-revolution Libya, Global Initiative against Transnational Organized Crime, Geneva, March 2017.

Mungianu R., Frontex and Non-Refoulement. The International Responsibility of the EU, Cambridge 2016.

Naples N.A., Mendez-Bickham J. (eds.), Border Politics. Social Movements, Collective Identities, and Globalization, New York-London 2015.

Newman D., "Contemporary Research Agendas in Border Studies: An Overview”, in D. Wastl-Walter (ed.), The Ashgate Research Companion to Border Studies, Farnham-Burlington, VT 2011.

Newman D., "On Borders and Power: A Theoretical Framework", Journal of Borderlands Studies, vol. 18, no. 1 (2003), at <https://doi.org/10.1080/08865655.2003.9695598>.

O'Brennan J., The Eastern Enlargement of the European Union, Abingdon-New York 2006.

“Operation Active Endeavour”, NATO, at <https://www.nato.int/cps/ic/natohq/topics_7932. htm>.

"Operation Mare Nostrum to End - Frontex Triton Operation Will Not Ensure Rescue at Sea of Migrants in International Waters", Asylum Information Database, 13 October 2014, at <http://www.asylumineurope.org/news/13-10-2014/operation-mare-nostrum-end-frontextriton-operation-will-not-ensure-rescue-sea $>$.

“Operation Sea Guardian”, NATO, at <https://www.nato.int/cps/ua/natohq/topics_136233. htm>.

Paasi A., "A Border Theory: An Unattainable Dream or a Realistic Aim for Border Scholars?”, in D. Wastl-Walter (ed.), The Ashgate Research Companion to Border Studies, Farnham-Burlington, VT 2011.

Pallister-Wilkins P., "Interrogating the Mediterranean 'Migration Crisis", Mediterranean Politics, vol. 21, no. 2 (2016), at <https://doi.org/10.1080/13629395.2016.1145826>.

Peers S., Rogers N. (eds.), EU Immigration and Asylum Law (Text and Commentary), Leiden-Boston 2006.

Reekum R. van, “The Mediterranean: Migration Corridor, Border Spectacle, Ethical Landscape”, Mediterranean Politics, vol. 21, no. 2 (2016), at <https://doi.org/10.1080/13629395.2016 $.1145828>$.

Refugee Council Information, Asylum Seekers in Europe, March 2017, at <https://www. refugeecouncil.org.uk/assets/0004/0083/Asylum_in_Europe_March_2017.pdf>.

Rieker P. (ed.), External Governance as Security Community Building. The Limits and Potential of the European Neighbourhood Policy, London 2016.

"Statement on the implementation of the Joint Declaration signed by the President of the European Council, the President of the European Commission, and the Secretary General of the North Atlantic Treaty Organization", NATO, 6 December 2016, at <https://www.nato.int/ cps/ua/natohq/official_texts_138829.htm>. 
Taylor A., "Why Britain Won't Save Drowning Migrants in the Mediterranean”, The Washington Post, 28 October 2014, at <https://www.washingtonpost.com/news/worldviews/ $\mathrm{wp} / 2014 / 10 / 28 /$ why-britain-wont-save-drowning-migrants-in-the-mediterranean/?utm _ term $=. \mathrm{d} 5 \mathrm{f} 885729210>$.

Walters W., "Border/Control”, European Journal of Social Theory, vol. 9, no. 2 (2006), at <https:// doi.org/10.1177/1368431006063332>.

Walters W., "Secure Borders, Safe Haven, Domopolitics", Citizenship Studies, vol. 8, no. 3 (2004), at <https://doi.org/10.1080/1362102042000256989>.

Wastl-Walter D. (ed.), The Ashgate Research Companion to Border Studies, Farnham-Burlington, VT 2011.

Weber L. (ed.), Rethinking Border Control for a Globalizing World. A Preferred Future, Abingdon-New York 2015.

Wilson T.M., Donnan H., "Borders and Border Studies”, in iidem (eds.), A Companion to Border Studies, Malden-Oxford 2012, at <http://dx.doi.org/10.1002/9781118255223.ch1>.

Wilson T.M., Donnan H. (eds.), A Companion to Border Studies, Malden-Oxford 2012.

Artur GRUSZCZAK - is Associate Professor of Political Science, Chair of National Security at the Faculty of International and Political Studies, Jagiellonian University in Kraków, Poland. His principal interests and research areas include: strategic studies; EU internal security; intelligence cooperation. Recently he published with Palgrave Macmillan Intelligence Security in the European Union. Building a Strategic Intelligence Community (2016). Forthcoming with Routledge is Technology, Ethics and the Protocols of Modern War (co-edited with Paweł Frankowski). 